\title{
How Can Psychology and Religious Aspects Affect on Fraud Tringle?
}

\author{
Bassem Ismail Yustrida Bernawati \\ Faculty of Economic and Business, Department of Accounting, University of Airlangga, Surabaya, Indonesia
}

\begin{abstract}
The purpose - In this paper, I explore the emphasis of the fraud triangle as a salutary model for practitioner to extract fraud. This paper is anchored through psychology and religious theories, and is propped with prove from holy books.

Findings - The findings point out that the Hawa Nafsu (HN) supporter and basic stone to control devil desire (DD) that control by humans lust (HL) that's present new model in preventing fraud. Fraud is a manifold phenomenon, whose religious theories may not fit all the cases into fixed model. Thus, fraud tringle not adequately credible model, so antifraud practitioner should consider fraud from religious perspective

Design/methodology/approach - The study uses secondary sources of information get it from magazine articles, textbooks and the Internet.

Theoretical implications - The discussion of the two theories contributes to understand frauds especially by legitimate accountants, auditors, fraudsters and other fraudulent entities. The study also serves as a guide to further research on fraud.
\end{abstract}

Keywords: Fraud triangle, fraud, Hawa Nafsu (HN) devil desire (DD), psychology, religious activities (RA).

DOI: $10.7176 /$ RJFA/10-1-06

\section{Introduction}

Many of the world's leading organizations have witnessed widespread fraud. This fraud was have an alarming impact on our global economy in addition to contributing to unnecessary suffering and increasing unemployment for the lower and middle classes. Fraud is expanding with propagation and rigidity.

The financial crisis of 2001 saw an extraordinary level of corporate accounting fraud, involving some huge companies in United States. Big headed from Enron, Tyco, WorldCom, Quest, and others companies were all tried condemned for involvement one of the fraud forms. A series of scandals to defeat American Economy, and many loyal workers who invested in company, pension, mutual funds their life savings (Gray et al., 2005).

Seven years later, in 2008, the global financial system hit the global financial crisis that changed Economic and Financial

World wide (Sikka, 2010). Immediately after the crisis alitany accounting companies Scandals began to write headlines. Some examples of these scandals included Bernard Madoff's plan Broke out in 2008. Madoff was condemned and sentenced to 150 years in prison for Ponzi Ani Laburti schemen $\$ 50$ billion (Henriques, 2009).

While accurate statistics are unknown, it has been estimated that the number of fraud investigator and auditors trained to disclose the fraud has exploded since the crises. The Assocication of certified fraud examiners (ACFE) which can be biggest fraud organization and the first provider of anti-fraud and education training, now has more than 70,000 members worldwide In the investigation of accounting and other frauds, ACF Eadvocates uses auditors and other anti-fraud specialists triangle fraud as a standard way to investigate to understand the factors that make people commit fraud (Lokanan, 2015).

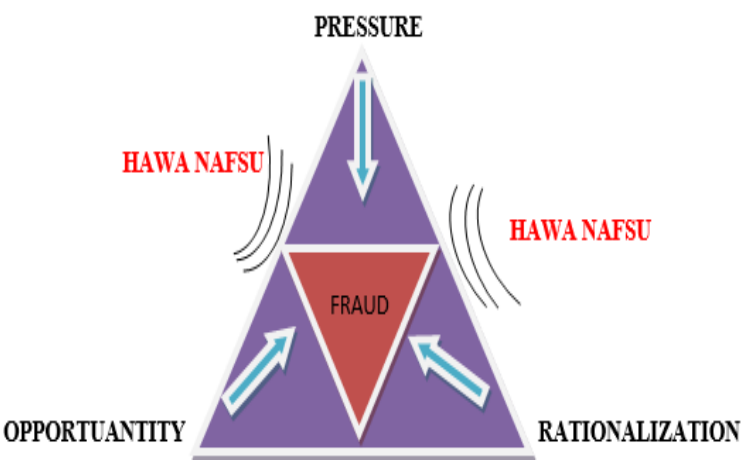

According to Cressey's book (1953) "Other People's Money: A Social Study" Psychology of embezzlement. Triangle Fraud Cressey (1953) it consists of three elements: pressure, opportunity and rationalization that shows in Fig .1.

Fig 1.1 Fraud Triangle adopted according to Cressey (1953).

All of which must exist to commit a crime Support for triangle fraud comes from audit professionals and ordinary settlers who argue that investigators who analyze the financial statements will be able to do so to determine the pressure (as in inflated income or net net income) that led to fraud. The opportunity to commit fraud with reference to the weakness or lack of adequate internal controls and rationalization techniques 
used to justify fraud (Standards, 2002).

In this Paper, we explore the allegation of the fraud triangle as a model to prevent fraud. providing evidence from spiritual perspective, I argue that the Fraud triangle is not sufficient for detecting fraud .specially I use Hawa Nafsu to show that human lust has devil desire to make fraud and it can be part of fraud tringale because every human can be influence by own soul to do wrong or good, while the spiritual activities can defeat devil soul in the time of three element of the fraud triangle, by the as a theoretical mooring and argue that the fraud triangle avow a body of knowledge that lack the objectives standard need to adequately statement every incidence of fraud.

\subsection{Why HN}

According to Al-Ghazali (1975) the term $\mathrm{Nafs}^{\mathbf{1}}$ from Arabic language has two aspects; one: to be launched and intended by the whole meaning of the abhorrent qualities, namely the animal forces against the mental forces; and the second: to be called and meant by the fact of Human and himself; so the soul of everything means the truth, and the essence that can replace the reasonable things, the place of divine .

Furthermore the general meaning of Nafsu either the power of anger and lust in human, or gentle, which is the human fact, the same person and his self, but they are described in different descriptions according to different conditions; if you lived under the command did not get the disorder because of opposition desires and our lust, called serene soul that can lead the human toward to the righteous as Allah says in holy Quran (QS 89:27-28) "It will be said to some) O, you serene soul! Come back to your Lord well-pleased (with Him) and well-pleasing (Him)"

And also mentioned in holy bible Romans 6:12 "Therefore do not let sin reign in your mortal body so that you obey its lusts" James 1:14 "But each one is temped when he is transported away and enticed by his own lust" Hence the soul in the first sense can not imagine its return to God; it is far from God (Al-Ghazali, 2010).

The latest neuroscience research provides important evidence that the brain of certain species is different from that of the rest of the population as in fig 1.2 While these results can improve our understanding of criminal behavior, they also raise moral dilemmas about whether society should use this knowledge to combat crime (Moskowitz, 2011). At the same time, to say that "greed and dishonesty" - common hearing referral can account for all that went on during the "irrational abundance" of the The 1990 and the early decades of the twenty-first century or earlier were too simplistic. In the business world, market participants are fully committed to the law they are not necessarily resort to fraud to achieve the goals stretch. From the perspective of criminology, collar crime, like other crime, can best be explained by three factors: the supply of motivation offenders, the availability of appropriate targets, and the absence of guardians who can control or someone who cares about the store" so to speak (Cohen and Felson 1979).

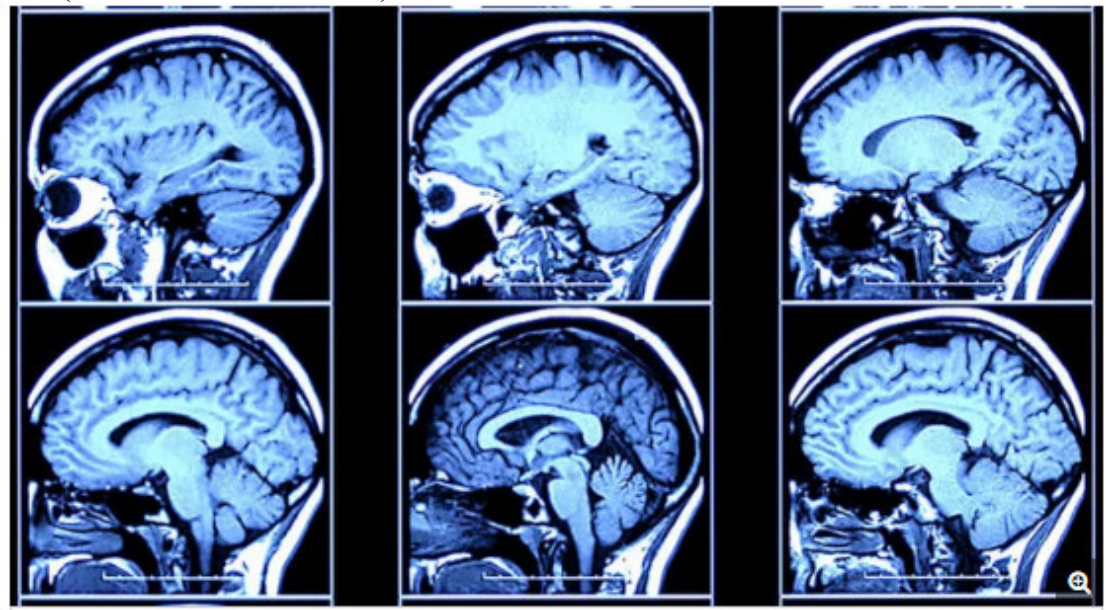

Fig .1.2 Show that brain scan for fraudulent is different from rest of population.

\subsection{Contribution of the paper}

The paper contributes to the continuing literature concern about the use of the fraud triangle to detect fraud in three ways (see Cooper \& Morgan, 2008; Dorminey, Fleming, Kranacher, \& Riley, 2012; Free \& Murphy, 2013; Morales, Gendron, \& Guénin-Paracini, 2014) for the first time the paper stretches the discussion about triangle fraud to provide a useful practitioner framework for detection and prevention Forgery. Adopted Morales

\footnotetext{
1 *Nafus litrary means Soul or psyche in English language though Muslims scholar has been differentiate between Soul and Nafsu.
} 
et al.(2014) theses are how the vision of fraud was built around the fraud triangle, which was developed following the establishment of fraud checking system (Foucault, 1969).

This paper adds to this search stream by installing the analysis within the $\mathrm{HN}$ and psychology aspects framework or familiar framework. Secondly, attention is drawn to the declaration and procedures of two professional anti-fraud bodies: ACFE and AICPA. These two bodies are dedicated and actively working to reduce the problem of fraud. Finally, with the increasing number of prominent accounting frauds throughout the popular press, there has been increased focus on fraud research.

The rest of the paper continues through three sections. In the first section, I scan the literature on the three legs of the fraud triangle, followed by the recovery review for the evolution of their own variables. This is. In Section two, review the latest work on accounting fraud, particularly institutional and broader society context in which there is. Section three concludes with a discussion of the implications of analysis of future research fraud and scholarship.

\section{RESULTS AND DISCUSSION}

\subsection{Pressure and rationalization to commit occupational fraud}

Cressey (1953) hypothesized that individuals commit fraud because of non-sharable financial pressure. Nonshareable financial pressure is a financial strain experienced by an individual, which he or she does not intend to share with others. The individual's inability to communicate the financial strain serves as a motivation to transgress the law in order to solve the problem.

Pressure and rationalization can not be observed, others important factors, such as the abilities of fraudsters ignore them. Thus, some researchers suggested the rational side must be replaced by the personal aspect Integrity because it can be more observable, others suggested motivation side needs to expand Non-financial factors such as ego and coercion, While others suggested adding a fourth to fraud triangle is a "fraudster character capabilities as identify in fig 2.1 the four element of fraud square. The literature on the pressure to commit occupational fraud can be broadly classified into financial pressures and non-financial pressures(AIC \& PwC, 2003; Albrecht \& Zimbelman, 2012; Fitzsimons, 2009).

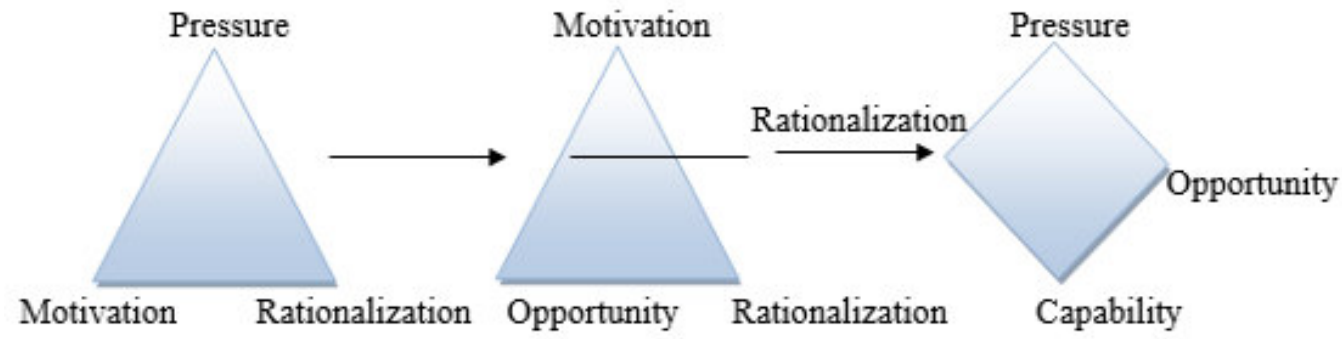

Fig.2.1 Evolution of fraud tringle .Source :complied by authors with references to Cressey (1953) Albrecht et al (2011).

\subsection{Opportunity to commit occupational fraud}

It was also stated that the perceived opportunity arose when the fraudster sees a way to use his position Trust in solving the financial problem, knowing it $\mathrm{He}$ is unlikely to be arrested. As for rationalization, Cressey mentioned most fraudsters are believed to be dissidents for the first time with no criminal record. They see themselves honest ordinary people who fell in bad shape Attitude. This enables them to justify the crime Themselves in a way that makes them acceptable or Justified (Cressey, 1953).

The soul is different according to its different conditions. If it turns to the rightness of the right, and recurrence with the outpouring of divine goodness, and the divine tranquility descends upon it, it will be assured of the remembrance of God Almighty, dwelling on the divine knowledge and flying to the top of the royal horizon which is mentioned in Surat Al-Fajr (27-30) as it show in fig 2.2 . While the forces in the quarrel and conflict, the frequency is taken to the side of the minds, receive the reasonable, and prove the acts of worship, and sometimes take over by the forces to be lower rock bottom; this soul is the same as a beasts. 


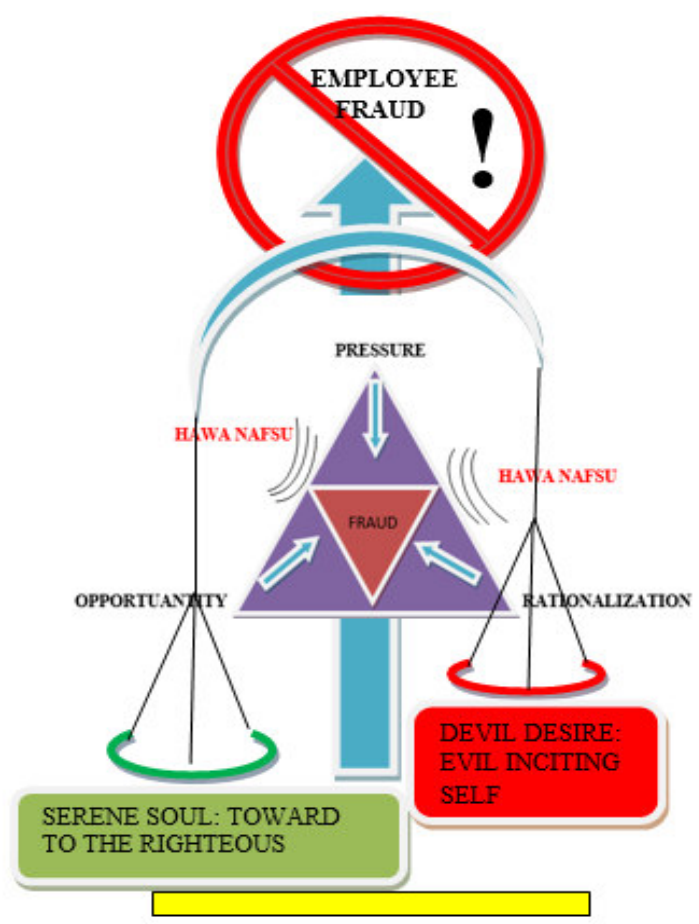

Fig 2.2 .Source: Made by Author

Generally, Psychology seeks to understand, explain, anticipate and observe individual and collective behavior. Specifically, personal psychology studies individuals. Social psychology is seen as a group Behavior; cross-cultural psychology (anthropology) analyzes the influence of culture and context on behavior and abnormal / personal / forensic psychology, sociology and psychiatry focus on deviant behavior (including, for example, industrial psychopaths). Criminal proceedings Psychology Psychological studies related to criminal behavior, criminal investigation, And the treatment of offenders (Colman, 2003).

Rationale of drawing on behavioral sciences it is clear from the intuition that one needs to think like a crook to catch a crook many business professionals, especially in the financial field, tend to reduce behaviors Explanations. But with the continued occurrence of fraud in growth, the spotlight Behavioral factors may be an important approach not only to detect fraud but to In other words, when discussing the subject of fraud, we must inevitably Bring the human factor (Ramamoorti, 2016).

\section{CONCLUSION}

Based on the result and discussion, it can be concluded that fraud triangle can be affected by own lust of the human through the devil desire this study motivated by many of lacking research that have been failed to fit one model for the fraud triangle, Results of this study religious theories has been shown to have a major effect On employee fraud, while the items in the fraud triangle (ie, pressure, opportunity, Rationalization) have positive effects on Employee fraud among executives its a great local authority.

It is more important to note that it is human beings who sometimes commit crimes as agents on behalf of their organizations, so we must try to understand their motives Identify both why and how white collar crime.

For institutions, Creating anti-fraud programs and controls is critical. To do this, understand the behavioral factors that affect the commission of fraud are the key to creating deterrent response fraud disclosure mechanisms and proactive risk management of financial fraud. Interestingly, the importance of behavioral science visions increases when we are moving to the field of fraud investigation as well as treatment.

\section{References}

Al-Quran al-karim

AIC, \& PwC. (2003). Serious fraud din Australia and New Zealand (No.48.). Research and Public Policy Series, Canberra.

Al-Ghazali. (1975). The gates of Jerusalem in the Nafsu tracks knowledge (2nd ed.). Beirut: New Horizons.

Al-Ghazali. (2010). Reviving the sciences of religion. Beirut: Dar al-Maarifa.

Albrecht, W. S., Albrecht, \& Zimbelman, M. F. (2011). Fraud examination. South-Western Pub.

Albrecht, \& Zimbelman. (2012). Fraud examination. Ohio South Western Cengage Learning. 
Ali, M. S. (2004). Holy Quran. Retrieved from https://www.alislam.org/quran/Holy-Quran-English.pdf

Cohen, I., \& Felson., M. (1979). Social change and crime rate trends: A routine activity approach. American Sociological Review, (44), 588-608.

Colman, A. M. (2003). Oxford Dictionary of Psychology. Oxford University Press. Oxford, UK.

Cooper, \& Morgan. (2008). Casestudyresearchinaccounting. Accounting Horizons, 22(2), 159-178.

Cressey. (1953). Other people's money:A study in the social psychology of embezzlement. California:Wadsworth.

Dorminey, Fleming, Kranacher, \& Riley. (2012). The evolution of fraud theory. Issues in Accounting Education, $7(2), 555-579$.

Fitzsimons. (2009). A troubled relationship:Corruption and reform of the public sector in development. Journal of Management Development, 28(6), 513-521.

Foucault. (1969). The archaeology of knowledge. London:Tavistock, ([fromFrench,Transl.A.M.Sheridan1972].).

Free, \& Murphy. (2013). The ties that bind:The decision to co-off end in fraud. Contemporary AccountingResearch. Retrieved from http://dx.doi.org/10.1111/\%0A1911-3846.12063

Gray, Frieder, \& Clark. (2005). Corporate scandals. :Themanyfacesofgreed. St.Paul:ParagonHouse.

Henriques. (2009). Madoff is sentenced to 150 yearsfor Ponzi scheme. Retrieved November 2, 2018, from http://www.nytimes.com/\%0A2009/06/30/business/30madoff.html?pagewanted=all\& r=0

Lokanan, M. E. (2015). Challenges to the fraud triangle: Questions on its usefulness. Accounting Forum, 39(3), 201-224. https://doi.org/10.1016/j.accfor.2015.05.002

Morales, Gendron, \& Guénin-Paracini. (2014). The construction of the risky individual and vigilant organization:Agenealogy of the fraud triangle. Accounting Organizations. Retrieved from http://dx.doi.org/10.1016/j.aos.2014.01.006

Moskowitz, C. (2011). Criminal Minds Are Different From Yours, Brain Scans Reveal. Retrieved from https://www.livescience.com/13083-criminals-brain-neuroscience-ethics.html

Ramamoorti, S. (2016). The Psychology and Sociology of Fraud. https://doi.org/10.2308/iace.2008.23.4.521

Sikka. (2010). Financial crisis and the silence of the auditors. Accounting Organizations and Society.

Standards, A. S. B. S. on A. (2002). Consideration of Fraud in a Financial Statement Audit. 